\title{
Two new species of Leptographium from Dryocetes authographus and Hylastes cunicularius in Norway
}

\author{
Karin Jacobs $^{1}$, Paal Krokene ${ }^{2}$, Halvor Solheim ${ }^{2}$ and Michael J. Wingfield ${ }^{3}$
}

(1) Department of Microbiology, University of Stellenbosch, Stellenbosch, 7600, South Africa

(2) Norwegian Forest and Landscape Institute, P.O. Box 115, 1431 Ås, Norway

(3) Forestry and Agricultural Biotechnology Institute, University of Pretoria, Pretoria, 0002, South Africa

\section{Karin Jacobs}

Email: kj@sun.ac.za

\begin{abstract}
The anamorph genus Leptographium Lagerberg and Melin includes species that are typically bark beetle-associated fungi, with teleomorphs in Grosmannia. During a survey of ophiostomatoid fungi in Norway, two unusual species, that fit the broader morphological description of Leptographium, were isolated directly from the root-feeding beetles, Dryocetes authographus and Hylastes cunicularius, as well as from roots infested by these insects. The first of these could be distinguished from other described species based on a sparse sporulation, black spore drops and chlamydospores in older cultures. This species also produces a Hyalorhinocladiella synanamorph. The second species was characterised by distinctly curved conidia. Based on these unusual morphological characteristics and distinct DNA sequences, these fungi were recognised as new taxa for which the names Leptographium chlamydatum sp. nov. and L. curvisporum sp. nov. are provided.
\end{abstract}

\section{Introduction}

The genus Leptographium was described in 1927 for fungi causing blue-stain on timber in Europe (Lagerberg et al. 1927). The taxonomic history of the genus was confused for many years due to segregate genera being established for groups with differing modes of conidium development (Kendrick 1961, 1962; Wingfield 1985). However, studies including those based on DNA sequence comparisons during the past two decades have led to a group that is phylogenetically and ecologically clearly defined (Jacobs et al. 2001, 2004, 2005, 2006; Kim et al. 2004, 2005a; Lee et al. 2005). Thus, Leptographium species are generally characterised by dematiaceous, erect conidiophores terminating in penicillate branches giving rise to conidiogenous cells bearing singlecelled conidia that accumulate in mucilaginous masses (Kendrick 1962; Jacobs and Wingfield 2001). These fungi are anamorphs of Grosmannia, a segregate of Ophiostoma sensu lato (Zipfel et al. 2006). Species of Grosmannia are typified by ascomata with globose bases, necks of variable length and cucullate ascospores produced in slimy masses (Jacobs and Wingfield 2001; Zipfel et al. 2006).

Leptographium species in Europe are mainly known from conifers where they exist in close association with insects, particularly bark beetles (Coleoptera: Curculionidae: Scolytinae), which may act as their primary vectors (Solheim and Långström 1991; Jacobs and Wingfield 2001). These include species such as L. wingfieldii M. Morlet, L. lundbergii Lagerb. \& Melin and L. penicillatum 
Grosmann (Lagerberg et al. 1927; Grosmann 1931; Morelet 1988; Jacobs et al. 2005). L. franckegrosmanniae K. Jacobs \& M.J. Wingf. is the only species known to occur specifically on hard woods in Europe (Davidson 1971).

A survey of ophiostomatoid fungi associated with the bark beetles Dryocetes autographus (Ratz.) and Hylastes cunicularius E. in Norway led to the isolation of two unusual Leptographium species. The objective of this study was to compare the strains from Norway with described species of Leptographium. This was achieved using DNA sequence and morphological comparisons.

\section{Materials and Methods}

\section{Isolations and isolates}

Strains treated in this study were isolated from Norway spruce (Picea abies) roots infested by intermingling Dryocetes autographus and Hylastes cunicularius beetles, as well as directly from the beetles. Roots of Norway spruce were examined for stained areas. Small pieces of the stained tissue were removed with a sterile scalpel and surfaces disinfected in commercial bleach, EtOH and $\mathrm{dH}_{2} \mathrm{O}$ $(10: 10: 80 \mathrm{v} / \mathrm{v})$. The surface-disinfected tissue pieces were then cut in half and placed on $2 \%$ Malt Extract Agar (MEA) (20 g Biolab malt extract, $20 \mathrm{~g}$ agar, 1,000 ml distilled water), containing cycloheximide and streptomycin sulfate, incubated at $22^{\circ} \mathrm{C}$ and later examined for fungal growth. Isolations directly from bark beetles were done by rinsing each beetle $(53 \mathrm{H}$. cunicularius and $20 \mathrm{D}$. autographus) in sterilised water and crushing them onto the surface of the same medium as above. Leptographium strains were identified under a dissection microscope and spore drops were transferred with a sterile needle to $2 \%$ MEA and incubated at $22^{\circ} \mathrm{C}$.

Strains used in this study are maintained in the culture collection (CMW) of the Forestry and Agricultural Biotechnology Institute (FABI), University of Pretoria (Table 1). Duplicates are also housed in the collection of the Norwegian Forest and Landscape Institute (NFLI), and representative isolates of taxonomically important strains have been deposited with the Centraalbureau voor Schimmelcultures (CBS), Netherlands and the herbarium of the ARC Plant Protection Research Institute (PREM) in Pretoria, South Africa.

\section{Phylogenetic analyses}

For phylogenetic comparisons, eight strains representing two Leptographium spp. that appeared different to the known Leptographium species, were grown on commercially available potato dextrose agar (PDA; Biolab, Johannesburg, South Africa) for 10 days at $25^{\circ} \mathrm{C}$. Mycelium was scraped from the colonies of pure cultures and DNA was extracted using the method of Möller et al. (1992) modified by Jacobs et al. (2004). The presence of DNA was confirmed under UV-light on a $1 \%$ agarose gel stained with ethidium bromide.

Gene regions used for the comparisons included the internal transcribed spacer (ITS2), part of the large subunit (28S) of the rDNA operon, $\beta$-tubulin and elongation factor $1-\alpha$ (EF 1- $\alpha$ ) genes as previously described by Jacobs et al. (2004). PCR reactions were performed in $25 \mu 1$ volumes (2.5 $\mathrm{mM} \mathrm{MgCl}{ }_{2}, 1 \times$ PCR buffer, $0.2 \mathrm{mM}$ dNTP, $0.2 \mathrm{mM}$ of each primer and $2.5 \mathrm{U}$ Taq-polymerase enzyme). Primers used in the amplification reactions and for cycle sequencing were ITS3 and LR3 (White et al. 1990) for the ITS2 and 28S region, Bt2a and Bt2b (Glass and Donaldson 1995) for the $\beta$-tubulin gene and EF1F and EF2R for the elongation factor 1- $\alpha$ gene (Jacobs et al. 2004). PCR products were purified using the Qiaquick PCR purification kit (Qiagen) and sequenced using the Big Dye terminator cycle sequencing premix kit (Applied Biosystems) on an ABI PRISM 3100 automatic sequencer (Perkin Elmer Applied Biosystems). Sequence contigs were assembled using Sequence Navigator (Applied Biosystems), aligned in ClustalX (Thompson et al. 1997) and 
manually adjusted in Se-Al (Rambaut 2007).

Table 1. Strains used in DNA-based comparisons and GenBank accession nos.

\begin{tabular}{|c|c|c|c|c|}
\hline Species & Strain no. & ITS & $\beta$-tubulin & Elongation $1-\alpha$ \\
\hline \multirow[t]{2}{*}{ L. trincatum } & CMW 30 & DQ062054 & DQ061988 & DQ062021 \\
\hline & CMW 28 & DQ062052 $2^{\mathrm{a}}$ & DQ061986 & DQ062019 \\
\hline \multirow[t]{2}{*}{ L. lundhergii } & CMW 217 & DQ062065 $5^{\mathrm{a}}$ & DQ061999 & DQ062032 \\
\hline & CMW 17264 & DQ062068 & DQ062002 & DQ062035 $5^{\circ}$ \\
\hline \multirow[t]{2}{*}{ L. donglasii } & CMW725 & AY $553380^{\circ}$ & AY $534928^{\circ}$ & AY $536174^{\circ}$ \\
\hline & CMW2078 & AY $553381^{2}$ & AY5 $34929^{\circ}$ & AY $536175^{\circ}$ \\
\hline L. neomexicanum & CMW2079 & AY $553382^{2}$ & AY $534930^{\circ}$ & AY $536176^{\circ}$ \\
\hline L. reconditum & CMW15 & AY $553383^{a}$ & AY5 $34931^{\circ}$ & AY $536177^{\circ}$ \\
\hline \multirow[t]{2}{*}{ L. serpens } & CMW193 & AY $553387^{\mathrm{a}}$ & AY5 $34935^{\circ}$ & AY $536181^{\circ}$ \\
\hline & CMW60 & AY $553388^{a}$ & AY5 $34936^{\circ}$ & AY $536182^{\circ}$ \\
\hline \multirow[t]{2}{*}{ L. aenigmatioum } & CMW2199 & AY $553389^{2}$ & AY $534937^{\circ}$ & AY $536183^{\circ}$ \\
\hline & CMW2310 & AY $553390^{\circ}$ & AY5 $34938^{\circ}$ & AY $536184^{\circ}$ \\
\hline \multirow[t]{2}{*}{ O. robustum } & CMW2805 & AY $553396^{\mathrm{a}}$ & AY5 $34944^{\circ}$ & AY $536190^{\circ}$ \\
\hline & CMW668 & AY $553397^{a}$ & AY5 $34945^{\circ}$ & AY $536191^{\circ}$ \\
\hline \multirow[t]{2}{*}{ L. aureum } & CMW709 & AY $553413^{a}$ & AY534961 ${ }^{\circ}$ & AY 536207 \\
\hline & CMW714 & DQ062071 $1^{\mathrm{a}}$ & $\mathrm{DQ} 062005^{\circ}$ & DQ062038 \\
\hline \multirow[t]{2}{*}{ L. pyrinum } & CMW509 & AY $553414^{a}$ & AY5 $34962^{\circ}$ & AY $536208^{\circ}$ \\
\hline & CMW169 & DQ062072 & DQ062006 & DQ062039 \\
\hline \multirow[t]{2}{*}{ L. yumnanensis } & CMW5304 & AY $553415^{a}$ & AY5 $34963^{\circ}$ & AY $536209^{\circ}$ \\
\hline & CMW5152 & DQ062073 $3^{\mathrm{a}}$ & $\mathrm{DQ} 062007^{\circ}$ & DQ062040 \\
\hline \multirow[t]{3}{*}{ L. wingfieldü } & CMW2095 & AY $553400^{\circ}$ & AY5 $34948^{\circ}$ & AY $536194^{\circ}$ \\
\hline & CMW 2096 & AY $553398^{a}$ & AY5 $34946^{\circ}$ & AY $536192^{\circ}$ \\
\hline & CMW2019 & AY 553399 & AY5 $34947^{\circ}$ & AY $536193^{\circ}$ \\
\hline \multirow[t]{2}{*}{ L. pineti } & CMW3831 & DQ062076 & DQ062010 $10^{\circ}$ & DQ062043 $3^{\circ}$ \\
\hline & CMW3837 & DQ06207 $\tau^{a}$ & DQ062011 & DQ062044 ${ }^{\circ}$ \\
\hline \multirow[t]{2}{*}{ L. americanum } & CMW495 & DQ062079 & DQ062013 & DQ062046 \\
\hline & CMW2929 & DQ062078 & DQ062012 $12^{\circ}$ & DQ062045 \\
\hline \multirow[t]{2}{*}{ L. abietinum } & CMW2817 & DQ062080 & DQ062014 & DQ062047 \\
\hline & CMW3083 & DQ06208 $1^{a}$ & DQ062015 & DQ062048 \\
\hline \multirow[t]{3}{*}{ L chlanydatum } & CMW11592 & EU979333 ${ }^{2}$ & EU979341 ${ }^{\circ}$ & EU979349 \\
\hline & CMW11597 & EU979334 & EU979342 & EU979350 \\
\hline & CMW11623 & EU979335 & EU979343 & EU979351 ${ }^{\circ}$ \\
\hline \multirow[t]{5}{*}{ L. cunvisporim } & CMW11 608 & EU979332a & EU979340 & EU979348 ${ }^{\circ}$ \\
\hline & NFRI 95-593/1 & EU979328 & EU979336 & EU979344 ${ }^{\circ}$ \\
\hline & NFRI 95-593/2 & EU979330 & EU979338 & EU979346 ${ }^{\circ}$ \\
\hline & NFRI 95-593/3 & EU979329a & EU979337 & EU979345 \\
\hline & NFRI 95-593/4 & EU979331 ${ }^{2}$ & EU979339 & EU979347 ${ }^{\circ}$ \\
\hline \multirow[t]{2}{*}{ L. laricis } & CMW1980 & DQ062074 & DQ062008 & DQ062041 $1^{\circ}$ \\
\hline & CMW2014 & DQ062075 & DQ062009 & DQ062042 $2^{\circ}$ \\
\hline
\end{tabular}


Phylogenetic relationships for the taxa were inferred using distance analysis in PAUP* v.4.0b10 (Swofford 2001). Characters were treated as unweighted in the analysis and gaps were treated as missing data. A single tree for each dataset was obtained using neighbour-joining analysis with an uncorrected P-distance and rooted to midpoint. A bootstrap analysis (1,000 replicates using the neighbour-joining option) was performed to determine the confidence levels of the nodes. For all the datasets, ambiguously aligned regions were replaced by codes. Step matrices to assign different weights to these codes were computed using INAASE 2.3b (Lutzoni et al. 2000). Both a partition homogeneity test (Farris et al. 1995) and a Templeton Nonparametric Wilcoxon Signed Ranked Test (Kellogg et al. 1996) was performed to determine whether the three datasets could be combined.

\section{Morphological comparisons}

All measurements and microscopic observations were made from 14-day-old fungal structures grown on 2\% MEA and oatmeal agar (OA) (30 g Jungle Oats; Tiger Consumer Brands, South Africa) (Gams et al. 1998) and incubated at $25^{\circ} \mathrm{C}$. Fungal structures were mounted on slides in $85 \%$ lactic acid and examined using phase or differential interference contrast microscopy. Fifty measurements were made for each morphological character and averages and standard deviations were computed.

\section{Results}

\section{Isolates and phylogenetic analyses}

Eight isolates representing two distinct morphological groups were collected from roots infested by Dryocetes autographus and Hylastes cunicularius, or from the insects themselves although at low frequencies $(\leq 5 \%)$. These isolates appeared to be morphologically distinct from all other species of Leptographium. Amplification of the ITS 2 and $28 \mathrm{~S}$ region, partial $\beta$-tubulin and partial EF 1- $\alpha$ genes resulted in fragments of approximately 700, 500 and 900 base pairs (bp), respectively. Results of both the partition homogeneity test (Farris et al. 1995) as well as a Templeton Nonparametric Wilcoxon Signed Ranked Test (Kellogg et al. 1996) showed that the three datasets could be combined.

The aligned combined dataset consisted of 1,992 characters. Twelve ambiguously aligned regions were identified ( $726 \mathrm{bp}$ in total) and excluded from the analysis. These regions were replaced with weighted codes as calculated using INAASE 2.3b (Lutzoni et al. 2000). The tree topologies resulting from analysis of the three separate datasets as well as those of the combined dataset were similar (data not shown).

In all cases, strains from Norway spruce grouped in two clades, distinct from each other and from other species of Leptographium. This was consistent with the fact that they are morphologically distinct from each other and apparently from other described species of Leptographium. The tree resulting from analysis of a combined dataset for all three gene regions showed that the strains represent two distinct taxa that are closely related to L. abietinum (Peck) M.J. Wingf. and $L$. americanum K. Jacobs \& M.J. Wingf. (Fig. 1). 


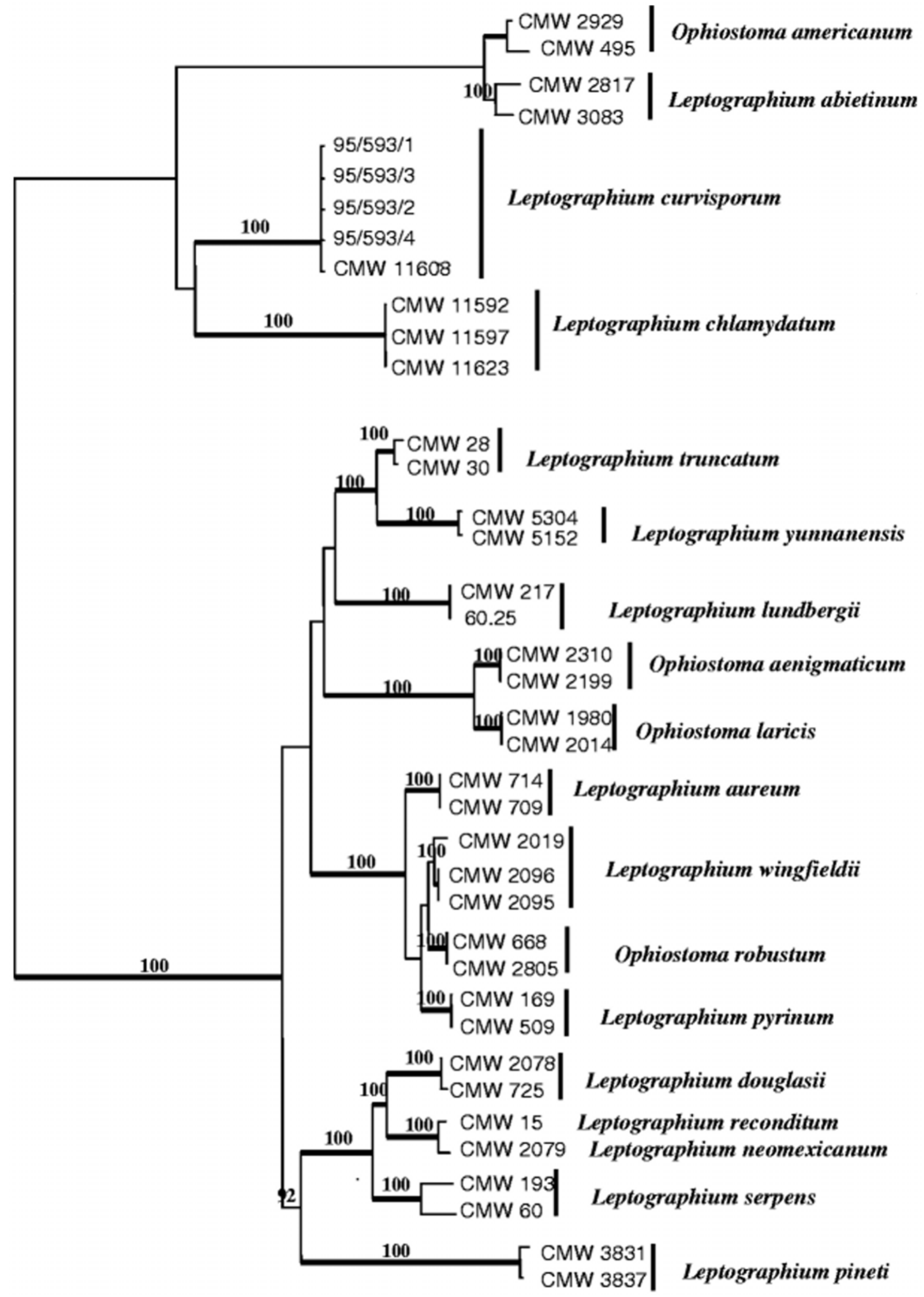

\subsection{5 changes}

Fig. 1. Neighbour-joining tree derived from analysis of the combined dataset. Branches in bold have bootstrap values above 85 . 


\section{Morphology}

The two unknown Leptographium spp. reflected by two distinct phylogenetic clades were morphologically distinct from each other as well as other Leptographium spp. (Table 2). Isolates from one of these clades could be distinguished from previously described species based on very sparse sporulation, black spore drops observed in older cultures as well as the presence of chlamydospores. This species is also unusual in that it produces a distinct Hyalorhinocladiella synanamorph, a character usually observed in anamorphs of Ophiostoma. The other group of isolates had distinctly curved conidia. In this respect, it resembled L. abietinum, which is a common inhabitant of various conifers infested by bark beetles in North America (Jacobs and Wingfield 2001). It could, however, be distinguished from this species based both on morphological differences and DNA sequence comparisons.

Table 2. Comparison of L. chlamydatum and L. curvisporum with closely related species based on morphology, ecology and geographic distribution.

\begin{tabular}{|c|c|c|c|c|}
\hline & L. abietinum & L. americanum & L. chlamydatum & L. cavvispornum \\
\hline Conidiophore length & $74-535(-570) \mu \mathrm{m}$ & $(150-) 210-455(-730) \mu \mathrm{m}$ & $(123-) 191-303(-359) \mu \mathrm{m}$ & $(139-) 179-349(-645) \mu \mathrm{m}$ \\
\hline Conidium shape & Distinctly curved at the base & Oblong to obovoid & Oblong to obovoid & Distinctly curved at the base \\
\hline Conidium size & $(3-) 4-5(-7) 1-2 \mu \mathrm{m}$ & $3-22 \times 1-3 \mu \mathrm{m}$ & $2-5(-7) \times 1-2 \mu \mathrm{m}$ & $3-4(-5) \times 1-2 \mu \mathrm{m}$ \\
\hline Rhizoids & Absent & Absent & Absent & Occasionally present \\
\hline Chlamydospores & Absent & Absent & Present & Absent \\
\hline Teleomorph & Absent & Ophiostoma & Absent & Absent \\
\hline Synanamorph & Absent & Absent & Hyalorhinocladiella & Absent \\
\hline \multirow[t]{8}{*}{ Host } & $\begin{array}{l}\text { Picea mariana } \\
\text { P. engelmannii }\end{array}$ & Larix decidua & Picea abies & Picea abies \\
\hline & Psendotsuga menziesii & & & \\
\hline & Pinus contorta & & & \\
\hline & P. sylvestris & & & \\
\hline & P. ponderasa & & & \\
\hline & P. aristata & & & \\
\hline & P. mugo & & & \\
\hline & P. monticola & & & \\
\hline \multirow[t]{4}{*}{ Insect associations } & Dendroctonus psendotsugae & Dendroctonus simplex & Hylastes aunicularius & Hylastes cuniaularius \\
\hline & $\begin{array}{l}\text { D. rufipennis } \\
\text { Hylastes longicollis }\end{array}$ & & Dnyocetes autographus & Dpocetes autographus \\
\hline & Hylurgops pormsus & & & \\
\hline & Hylurgops planirostris & & & \\
\hline $\begin{array}{l}\text { Geographic } \\
\text { distribution }\end{array}$ & Northwestern United States & $\begin{array}{l}\text { Northeastern } \\
\text { United States }\end{array}$ & Norway & Norway \\
\hline
\end{tabular}

Based primarily on phylogenetic differences but also morphological features and a distinct ecology, the two Leptographium spp. from Norway are described as follows.

Leptographium chlamydatum K. Jacobs, M.J. Wingf. \& H. Solheim sp. nov. (Figs. 2 and 3)

MycoBank: 515125

Etymology: The specific epithet refers to the chlamydospores in older cultures of this species.

Description: Conidiophora singula e mycelio proxime orientia, macronemata, mononemata, (144-) 195-396 (-580) $\mu \mathrm{m}$ longa, sine structuris rhizoidiformibus. Apparatus conidiogenus (25-) 37-60 (72) $\mu \mathrm{m}$ longus, massa conidiorum exclusa, ramis cylindricis multiseriatis. Conidia hyalina non septata, oblonga vel obovoidea basibus truncatis apicibus rotundatis $3-5(-6) \times 2-3 \mu \mathrm{m}$. Synanamorpha in firma Hyalorhinocladiellae (7-) 8-72 (-137) $\mu \mathrm{m}$ longa, 2-3 $\mu \mathrm{m}$ lata. Chlamydosporae in culturis vetustioribus videntur (5-) 9-16 (-20) $\mu \mathrm{m}$ diametro. 


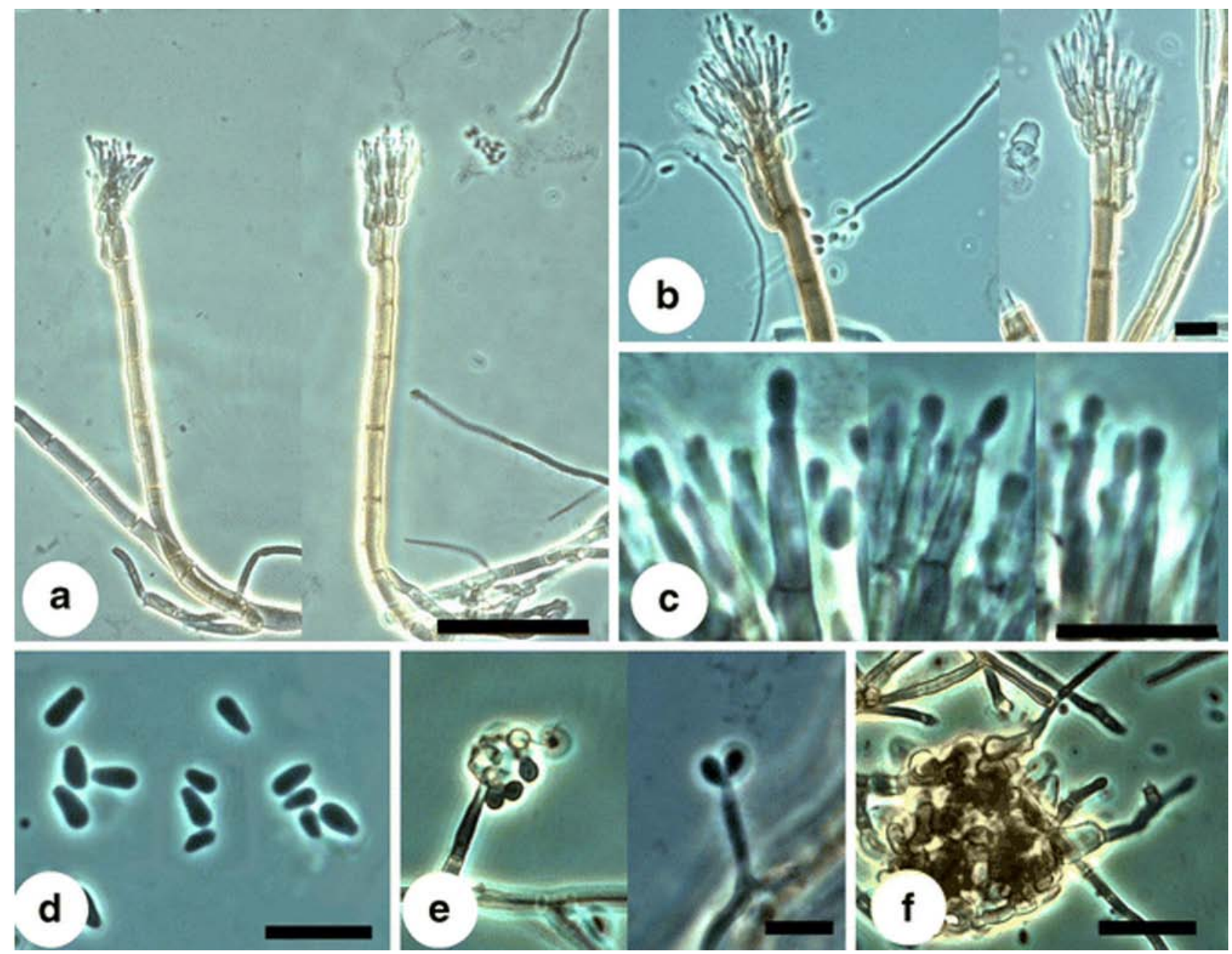

Fig. 2. Light micrographs of the morphological characters of Leptographium chlamydatum (CMW 11592). a Conidiophore morphology, bar $20 \mu \mathrm{m}$. b Conidiogenous apparatus with two primary branches. c Conidiogenous cells showing annelidic conidium development and delayed secession of conidia, bar $10 \mu \mathrm{m}$. d Obovoid conidia with almost tapered ends, bar $10 \mu \mathrm{m}$. e Hyalorhinocladiella synanamorph bar $10 \mu \mathrm{m}$. f Chlamydospore-like structures, bar $20 \mu \mathrm{m}$.

Conidiophores occurring singly arising directly from the mycelium, macronematous, mononematous, (144-) 195-396 (-580) $\mu \mathrm{m}$ in length, rhizoid-like structures absent (Figs. 2a, 3a). Stipes light olivaceous, cylindrical, simple, 6-24-septate, (119-) 150-344 (-529) $\mu \mathrm{m}$ long, apical cell not swollen, basal cell occasionally slightly swollen. Conidiogenous apparatus (25-) 37-60 (72) $\mu \mathrm{m}$ long, excluding the conidial mass, with multiple series of cylindrical branches. Primary branches, 2-4, light olivaceous, smooth, cylindrical, aseptate, (9-) 10-15 (-17) $\mu \mathrm{m}$ long and 4-5 (6) $\mu \mathrm{m}$ wide, arrangement of the primary branches on the stipe-type B (more than two branches) (Fig. 2b). Conidiogenous cells discrete, 2-3 per branch, cylindrical, tapering slightly at the apex, (7-) 9-13 (-18) $\mu \mathrm{m}$ long and 1-3 $\mu \mathrm{m}$ wide. Conidium development according to van Wyk et al. (1988) (Fig. 2c). Conidia hyaline, aseptate, oblong to obovoid with truncate bases and rounded apices, 3-5 $(-6) \times 2-3 \mu \mathrm{m}$ (Figs. $2 \mathrm{~d}$ and $3 \mathrm{c}$ ). Hyphae submerged in agar with abundant aerial mycelium, smooth, serpentine, occasionally constricted at the septa, $(2-) 3-5(-8) \mu \mathrm{m}$ wide. Hyalorhinocladiella-type synanamorph, (7-) 8-72 (-137) $\mu \mathrm{m}$ long, $2-3 \mu \mathrm{m}$ wide (Figs. 2e and 3c). Chlamydospores present in older cultures, 2-4 weeks, (5-) 9-16 (-20) $\mu \mathrm{m}$ in diameter (Fig. 2f and 3d). 

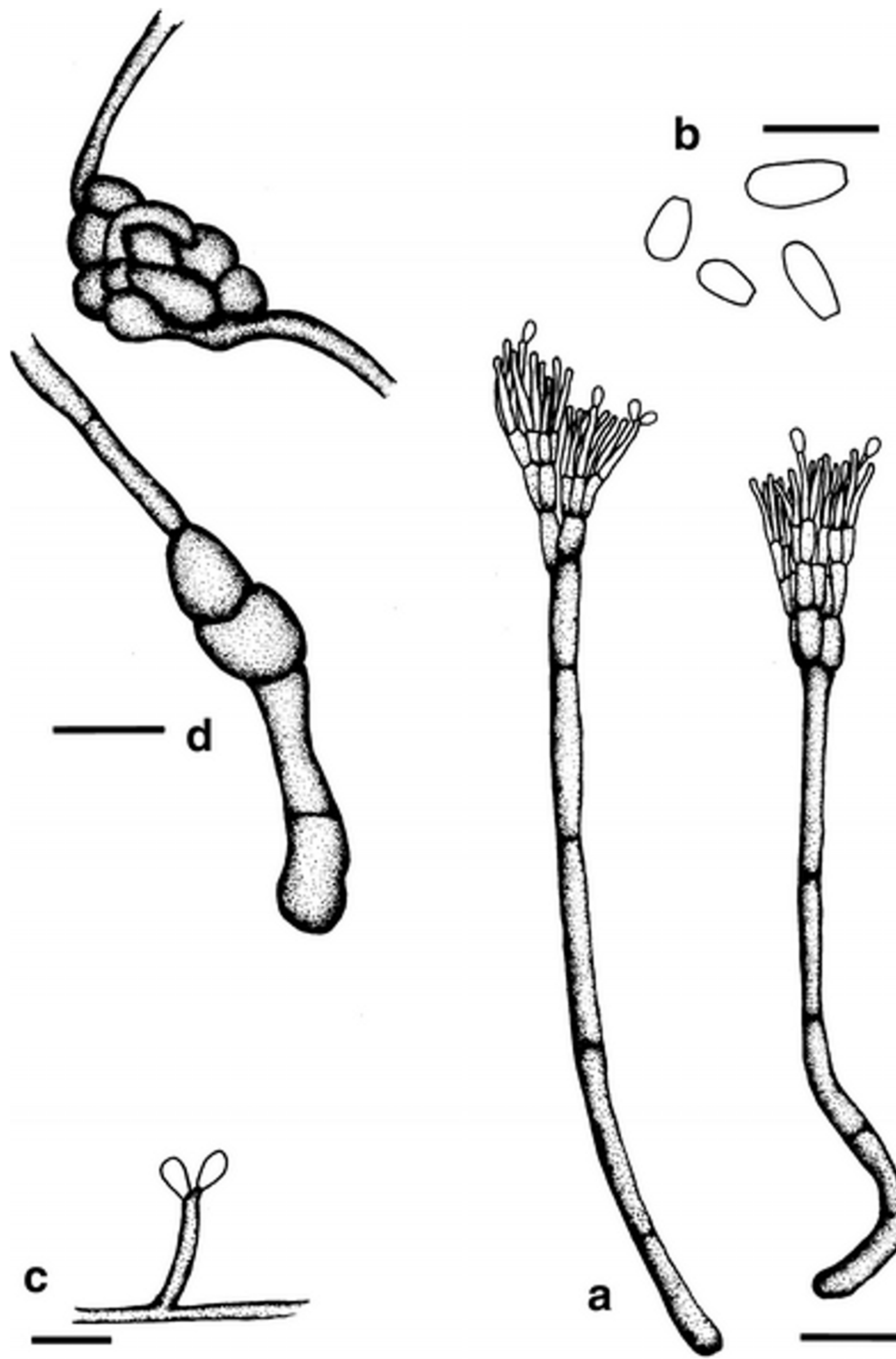
Fig. 3. Line drawings of the morphological characters of Leptographium chlamydatum (CMW 11592). a Conidiophore morphology, bar $10 \mu \mathrm{m}$. b Obovoid conidia with almost tapered ends, bar $10 \mu \mathrm{m}$. c Hyalorhinocladiella synanamorph of L. chlamydatum, bar $20 \mu \mathrm{m}$. d Chlamydospore-like structures, bar10 $\mu \mathrm{m}$

Specimens examined: Norway, Ås, Akershus, all collected by H. Solheim and M.J. Wingfield, Aug. 1995; isolated from Dryocetes autographus PREM 60044 (CMW 11592; NFLI 95-593/82) (holotype); additional specimens: isolated from Hylastes cunicularius CMW 11623 (NFLI 95593/131; CBS 123915); CMW 11597 (NFLI 95-593/132).

Leptographium curvisporum K. Jacobs, M.J. Wingf. \& H. Solheim sp. nov. (Figs. 4 and 5)
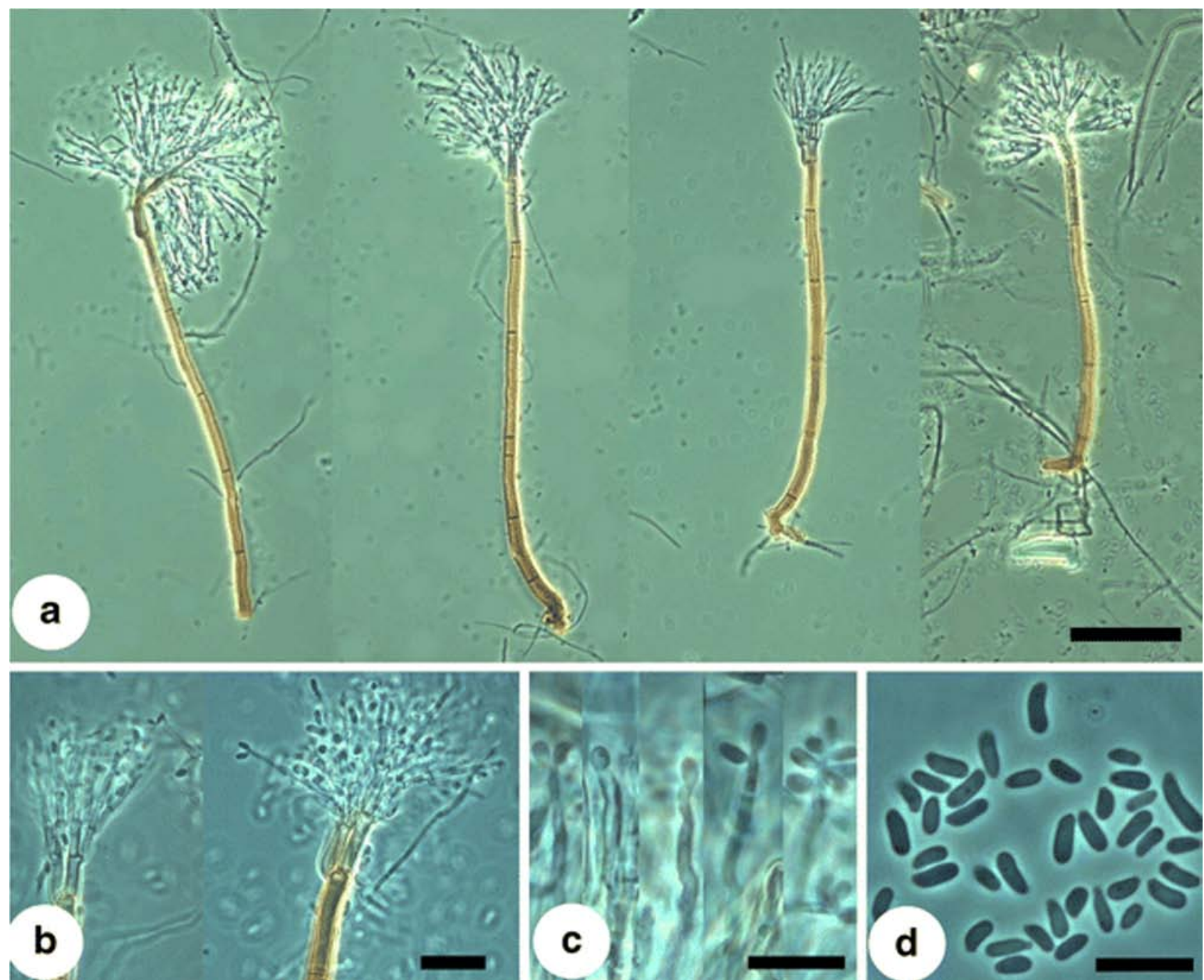

Fig. 4. Light micrographs of the morphological characters of Leptographium curvisporum (CMW 11608). a Variation in conidiophore morphology, bar $20 \mu \mathrm{m}$. b Conidiogenous apparatus with two or three primary branches. c Conidiogenous cells showing annelidic conidium development and delayed secession of conidia, bar $10 \mu \mathrm{m}$. d Curved conidia with tapered ends, bar $10 \mu \mathrm{m}$. 

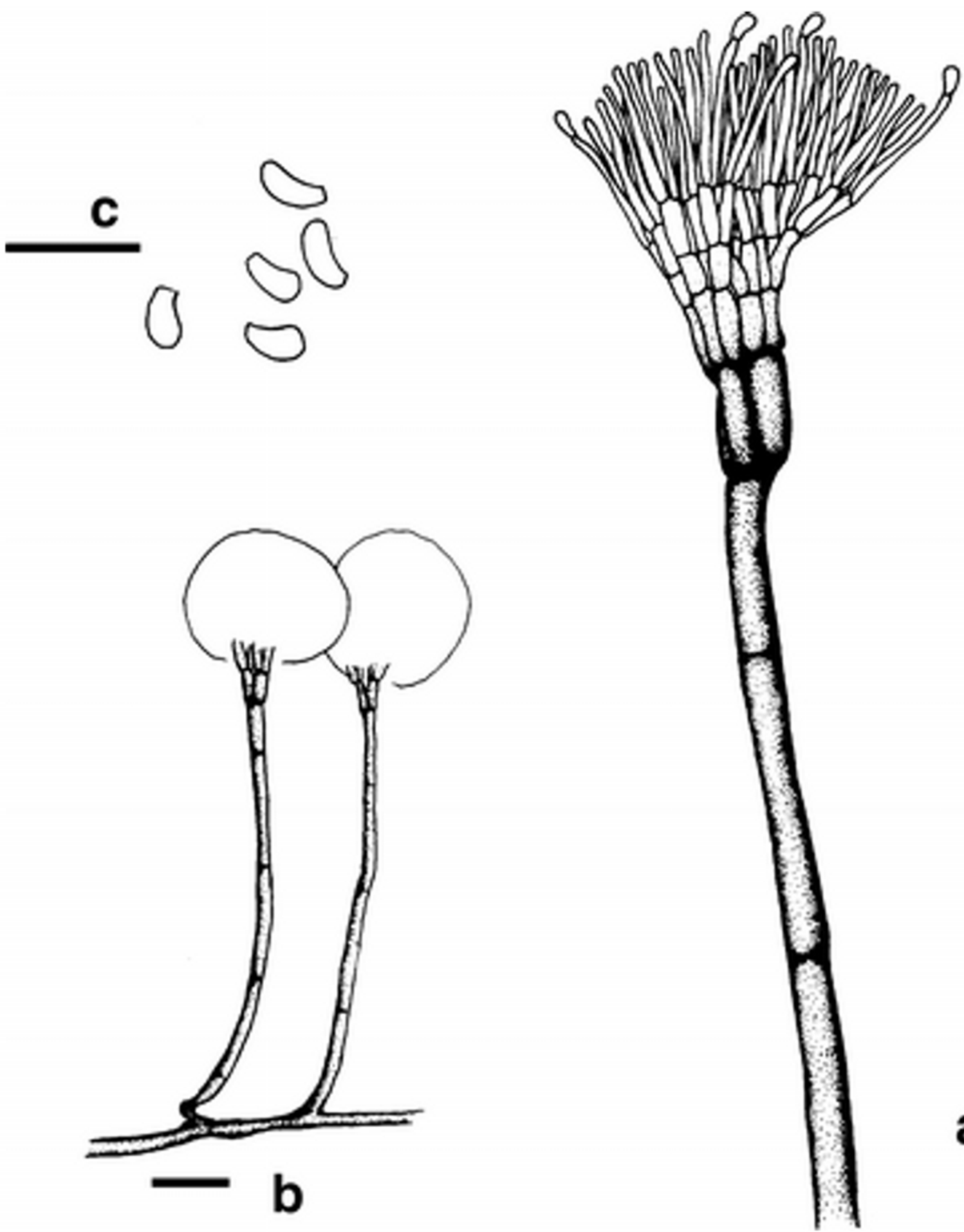

Fig. 5. Line drawings of the morphological characters of Leptographium curvisporum (CMW 11608). a Conidiogenous apparatus with three primary branches, bar $10 \mu \mathrm{m}$. b Habit sketch showing single arrangement of condiophores, bar $20 \mu \mathrm{m}$. c Curved conidia with tapered ends, bar $10 \mu \mathrm{m}$

MycoBank: 515126

Etymology: The specific epithet refers to the distinctly curved conidia of this species.

Description: Conidiophora singula e mycelio proxime orientia, macronemata, mononemata, (139-) 179-349 (-645) $\mu \mathrm{m}$ longa, aliquando cum structuris rhizoidiformibus. Apparatus conidiogenus (36-) 52-82 (-125) $\mu \mathrm{m}$ longus, massa conidiorum exclusa, ramis cylindricis multiseriatis. Conidia 
hyalina non septata, oblonga vel obovoidea basibus truncatis subcurvatis, apicibus rotundatis 3-4 (5) $\times 1-2 \mu \mathrm{m}$.

Conidiophores occurring singly arising directly from the mycelium, macronematous, mononematous, (139-) 179-349 (-645) $\mu \mathrm{m}$ in length, rhizoid-like structures occasionally present. Stipes light olivaceous, cylindrical, simple, 4-8-septate, (76-) 118-278 (-545) $\mu \mathrm{m}$ long, apical cell not swollen, basal cell not swollen (Figs. 4a and 5a). Conidiogenous apparatus (36-) 52-82 (-125) $\mu \mathrm{m}$ long, excluding the conidial mass, with multiple series of cylindrical branches. Primary branches, 2-3, light olivaceous, smooth, cylindrical, aseptate, (9-) 11-16 (-21) $\mu \mathrm{m}$ long and (2-) 3$5(-6) \mu \mathrm{m}$ wide, arrangement of the primary branches on the stipe-type B (more than two branches) (Fig. 4b). Conidiogenous cells discrete, 2-3 per branch, cylindrical, tapering slightly at the apex, (10-) 11-19 (-25) $\mu \mathrm{m}$ long and 1-2 $\mu \mathrm{m}$ wide. Conidium development as described by van Wyk et al. (1988) (Fig. 4c). Conidia hyaline, aseptate, oblong to obovoid with truncate bases that are slightly curved and rounded apices, 3-4 (-5) $\times 1-2 \mu \mathrm{m}$ (Figs. $4 \mathrm{~d}$ and 5c).

Specimens examined: Norway, Ås, Akershus, Picea abies infested with Dryocetes autographus and Hylastes cunnicularius, collected by H. Solheim and M.J. Wingfield, Aug. 1995, PREM 60035 (CMW 17260; NFLI95-593/1; CBS123914) (holotype). Additional specimens: Norway, Ås, Akershus, Picea abies infested with Dryocetes autographus and Hylastes cunicularius, collected by H. Solheim and M.J. Wingfield, Aug. 1995, CMW 17261 (NFLI 95-593/2); CMW 17262 (NFLI 95593/3; CBS 124006); CMW 11608 (NFLI 95-593/4); CMW 17263 (PREM 60036; NFLI 95-593/5).

\section{Discussion}

Two new species of Leptographium emerged from this study. These fungi are potential associates of the root-feeding bark beetles Dryocetes autographus and Hylastes cunicularius. One of the fungi, L. chlamydatum, was isolated from the bark beetles, while L. curvisporum was isolated from diseased $P$. abies tissue infested by these beetles. These results are not unusual as many Leptographium spp. are associated with root-feeding bark beetles. For example, L. wageneri var. pseudotsugae T.C. Harr. \& F.W. Cobb is commonly associated with Hylastes nigrinus Mann. in western North America (Witcosky et al. 1986; Harrington 1993), and L. truncatum (M.J. Wingf. \& Marasas) M.J. Wingf. and L. serpens (Goid.) M.J. Wingf. are closely associated with Hylastes angustatus (Herbst) in South Africa, where the insect is an introduced exotic (Wingfield and Marasas 1980, 1981). Likewise, L. huntii M.J. Wingf. is commonly associated with the introduced H. ater (F.) in both Chile (Zhou et al. 2004) and New Zealand (Kim et al. 2005b).

Leptographium chlamydatum can easily be distinguished from other Leptographium spp. by the presence of clumps of thick-walled cells in older cultures, usually older than 2 weeks. These resemble the chlamydospores occasionally observed in Phoma spp. (Camyon and Gerhardson 1997). Chlamydospores are commonly found in a number of other fungal genera where they are believed to facilitate survival. Although various species of Ceratocystis produce well-developed and very obvious chlamydospores (Upadhyay 1981; Barnes et al. 2003; Johnson et al. 2005), this character has been observed only in one other species of Leptographium, L. piriforme Greif, Gibas \& Currah (Greif et al. 2006).

Leptographium clamydatum also produces a very distinct Hyalorhinocladiella synanamorph in culture and these structures can aid in identifying the fungus. Production of synanamorphs in Leptographium spp. is not common but is also not without precedent. For example, L. elegans M.J. Wingf., Crous \& Tzean and L. bistatum J.-J. Kim \& G.-H. Kim produce very obvious Sporothrix states (Wingfield et al. 1994; Kim et al. 2004). As in the case of the chlamydospores, Hyalorhinocladiella-type synanamorphs have been described only in Leptographium piriforme, although they are common in species of Ophiostoma (Hunt 1956; Upadhyay 1981; Kirschner and 
Oberwinkler 1999; Jacobs and Kirisits 2003; Jacobs et al. 2003). Hyalorhinocladiella anamorphs might be considered reduced forms of the conidiogenous cells of Leptographium or Pesotum, but those formed in L. chlamydatum appear to represent a distinctly functional anamorph state.

Leptographium curvisporum is phylogenetically closely related to L. chlamydatum. Both these species group together with $L$. abietinum and L. americanum in a clade distinct from other Leptographium spp. Morphologically, L. curvisporum most closely resembles L. abietinum. The latter species is primarily known from the northwestern USA and Western Canada, where it occurs on various conifers, is carried by bark beetles and is considered to be weakly pathogenic (Kendrick 1962; Reynolds 1992; Ross and Solheim 1997; Solheim and Safranyik 1997; Solheim and Krokene 1998). Other than its distinct ecological niche, L. curvisporum can be distinguished from $L$. abietinum based on the presence of knob-like rhizoids, which are absent in L. abietinum. The conidia of L. curvisporum are also distinctly smaller than those of L. abietinum.

Ophiostomatoid fungi have been relatively well studied in Europe and the discovery of two new species associated with relatively well-known insects was surprising. This might be explained by the fact that the insects have a root-feeding habit and this niche has not been afforded much attention in the past (Mathiesen-Käärik 1953). Clearly, the inventory of Leptographium species, even in countries where these fungi are well known, is incomplete. More intensive surveys and especially those focussed on root-feeding insects are likely to yield substantial numbers of new Leptographium spp., which will expand our understanding of these interesting and often important fungi.

\section{Acknowledgments}

We acknowledge the National Research Foundation (NRF), Tree Pathology Cooperative Programme (TPCP), University of Pretoria, South Africa; Norwegian Research Council (NFR) and Norwegian Forest and Landscape Institute (Skog og landskap) for financial support. We are also indebted to Dr. Hugh Glen for providing the Latin diagnoses.

\section{Literature Cited}

Barnes I, Roux J, Wingfield BD, Dudzinski MJ, Old KM, Wingfield MJ (2003) Ceratocystis pirilliformis, a new species from Eucalyptus nitens in Australia. Mycologia 95:865-871.

Camyon S, Gerhardson B (1997) Formation of pseudosclerotia and bacteria-induced agents of chlamydospores in Phoma foveata. Eur J P1 Pathol 103:467-470.

Davidson RW (1971) New species of Ceratocystis. Mycologia 63:5-15.

Farris JS, Källersjö M, Kluge AG, Bult C (1995) Testing significance of incongruence. Cladistics 10:315-319.

Gams W, Hoekstra ES, Aproot A (1998) CBS course of mycology, 4th edn. Centraalbureau voor Schimmelcultures, Baarn.

Glass NL, Donaldson GC (1995) Development of primer sets designed for use with the PCR to amplify conserved genes from filamentous ascomycetes. Appl Environ Microb 61:1323-1329.

Greif MD, Gibas CFC, Currah RS (2006) Leptographium piriforme sp. nov. from a taxonomically diverse collection of anthropods collected in an aspen-dominated forest in western Canada. 
Mycologia 98:771-780.

Grosmann H (1931) Contributions to the knowledge concerning the life partnership between bark beetles and fungi. Z ParasitKde 3:56-102.

Harrington TC (1993) Diseases of conifers caused by species of Ophiostoma and Leptographium. In: Wingfield MJ, Seifert KA, Webber JF (eds) Ceratocystis and Ophiostoma: taxonomy, ecology and pathogenicity. APS Press, St. Paul, Minnesota, USA, pp 161-172.

Hunt J (1956) Taxonomy of the genus Ceratocystis. Lloydia 19:1-58.

Jacobs K, Kirisits T (2003) Ophiostoma kryptum sp. nov. from Larix decidua and Picea abies in Europe, similar to O. minus. Mycol Res 107:1231-1242.

Jacobs K, Wingfield MJ (2001) Leptographium species: tree pathogens, insect associates and agents of blue-stain. APS Press, St. Paul, Minnesota, USA.

Jacobs K, Wingfield MJ, Wingfield BD (2001) Phylogenetic relationships in Leptographium based on morphological and molecular characters. Can J Bot 79:719-732.

Jacobs K, Seifert KA, Harrison KJ, Kirisits T (2003) Identity and phylogenetic relationships of Ophiostomatoid fungi associated with invasive and native Tetropium spp. (Coleoptera:

Cerambycidae) in Atlantic Canada. Can J Bot 81:316-329.

Jacobs K, Bergdah DR, Wingfield MJ, Halik S, Seifert KA, Bright DE, Wingfield BD (2004) Leptographium wingfieldii introduced into North America and found associated with exotic Tomicus piniperda and native bark beetles. Mycol Res 108:411-418.

Jacobs K, Solheim H, Wingfield BD, Wingfield MJ (2005) Taxonomic re-evaluation of Leptographium lundbergii based on DNA sequence comparisons and morphology. Mycol Res 109:1149-1161.

Jacobs K, Eckhardt L, Wingfield MJ (2006) Leptographium profanum sp. nov. a new species of Leptographium from hardwood roots in North America. Can J Bot 84:759-766.

Johnson JA, Harrington TC, Engelbrecht CJB (2005) Phylogeny and taxonomy of the North American clade of the Ceratocystis fimbriata complex. Mycologia 97:1067-1092.

Kellogg EA, Appels R, Mason-Gamer RJ (1996) When genes tell different stories: the diploid genera of Triticeae. Syst Bot 21:321-347.

Kendrick WB (1961) The Leptographium complex. Phialocephala gen.nov. Can J Bot 39:10801085.

Kendrick WB (1962) The Leptographium complex. Verticicladiella S. Hughes. Can J Bot 40:771797.

Kim JJ, Lim YW, Wingfield MJ, Breuil C, Kim GH (2004) Leptographium bistatum sp. nov. a new species with a Sporothrix synanamorph from Pinus radiata in Korea. Mycol Res 108:699-706.

Kim J-J, Lim YW, Breuil C, Wingfield MJ, Zhou XD, Kim G-H (2005a) A new Leptographium species associated with Tomicus piniperda infesting pine logs in Korea. Mycol Res 109:275-284. 
Kim GH, Kim JJ, Lim YW, Breuil C (2005b) Ophiostomatoid fungi isolated from Pinus radiata logs imported from New Zealand to Korea. Can J Bot 83:272-278.

Kirschner R, Oberwinkler F (1999) A new Ophiostoma species associated with bark beetles infesting Norway spruce. Can J Bot 77:247-252.

Lagerberg T, Lundberg G, Melin E (1927) Biological and practical researches into blueing in pine and spruce. Sver SkogsvFör Tidskr 25:145-272.

Lee S, Kim JJ, Breuil C (2005) Leptographium longiclavatum sp. nov. a new species associated with the mountain pine beetle, Dendroctonus ponderosae. Mycol Res 109:1162-1170.

Lutzoni F, Wagner P, Reeb V, Zoller S (2000) Integrating ambiguously aligned regions of DNA sequences in phylogenetic analyses without violating positional homology. Syst Biol 49:628-651.

Mathiesen-Käärik A (1953) Eine Übersicht über die gewöhnlichsten mit Borkenkärfern assiziierten Bläuepilze in Schweden und einige für Schweden neue Bläuepilze. Meddn St SkogforskInst 43:374.

Möller EM, Bahnweg G, Sandermann H, Geiger HH (1992) A simple and efficient protocol for isolation of high molecular weight DNA from filamentous fungi, fruit bodies, and infected plant tissues. Nucl Acids Res 20:6115-6116.

Morelet M (1988) Observations sur trios Deutéromycètes inféodés aux pins. Ann Soc Sci Nat Archéol Toulon 40:41-43.

Rambaut A (2007) Se-Al: sequence alignment editor. Available from http://evolve.zoo.ox.ac.uk/

Reynolds KM (1992) Relations between activity of Dendroctonus rufipennis Kirby on Lutz spruce and blue-stain associated with Leptographium abietinum (Peck) Wingfield. For Ecol Manage 47:71-86.

Ross DW, Solheim H (1997) Pathogenicity to Douglas-fir of Ophiostoma pseudotsugae and Leptographium abietinum, fungi associated with the Douglas-fir beetle. Can J Bot 27:39-43.

Solheim H, Krokene P (1998) Growth and virulence of Ceratocystis rufipenni and three blue-stain fungi isolated from the Douglas-fir beetle. Can J Bot 76:1763-1769.

Solheim H, Långström B (1991) Blue-stain fungi associated with Tomicus piniperda in Sweden and preliminary observations on their pathogenicity. Ann Sci For 48:149-156.

Solheim H, Safranyik L (1997) Pathogenicity to Sitka spruce of Ceratocystis rufipenni and Leptographium abietinum, blue-stain fungi associated with the spruce beetle. Can J Bot 27:13361341.

Swofford DL (2001) PAUP*: phylogenetic analysis using parsimony (*and other methods). Version 4.0. Sinauer Associates, Sunderland, MA, USA.

Thompson JD, Gibson TJ, Plewniak F, Jeanmougin F, Higgins DG (1997) The ClustalX windows interface: flexible strategies for multiple sequence alignment aided by quality analysis tools. Nucl Acids Res 24:4876-4882. 
Upadhyay HP (1981) A monograph of Ceratocystis and Ceratocystiopsis. University of Georgia Press, Athens, GA.

Van Wyk P, Wingfield MJ, Marasas WFO (1988) Differences in synchronisation of stages of conidial development in Leptographium species. Trans Br Mycol Soc 90:451-456.

Wingfield MJ (1985) Reclassification of Verticicladiella based on conidial development. Trans $\mathrm{Br}$ Mycol Soc 85:81-93.

Wingfield MJ, Marasas WFO (1980) Verticicladiella alacris sp. nov. associated with root disease of pines in South Africa. Trans Br Mycol Soc 75:21-28.

Wingfield MJ, Marasas WFO (1981) Verticicladiella alacris, a synonym of $V$. serpens. Trans Br Mycol Soc 76:508-510.

Wingfield MJ, Crous PW, Tzean SS (1994) Leptographium elegans: a new species from Taiwan. Mycol Res 98:781-785.

Witcosky JJ, Schowalter TD, Hansen EM (1986) Hylastes nigrinus (Coleoptera: Scolytidae), Pissodes fasciates, and Steremnius carinatus (Coleoptera: Curculionidae) as vectors of black-stain root disease of Douglas-fir. Environ Entomol 15:1090-1095.

White TJ, Bruns T, Lee S, Taylor J (1990) Amplification and direct sequencing of fungal ribosomal RNA genes for phylogenitics. In: Innis MA, Gelfand DH, Sninsky JJ, White TJ (eds) PCR protocols: A guide to methods and applications. Academic, San Diego, USA, pp 315-322.

Zhou XD, de Beer ZW, Ahumada R, Wingfield BD, Wingfield MJ (2004) Ophiostoma and Ceratocystis spp associated with two pine infesting bark beetles in Chile. Fungal Divers 15:261274.

Zipfel RD, de Beer ZW, Jacobs K, Wingfield BD, Wingfield MJ (2006) Multigene phylogenies define Ceratocystiopsis and Grosmannia distinct from Ophiostoma. Stud Mycol 55:75-97. 